\title{
Inhalt
}

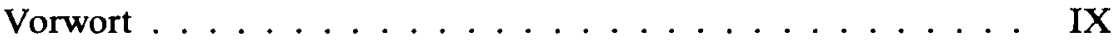

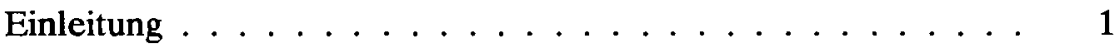

Erstes Kapitel

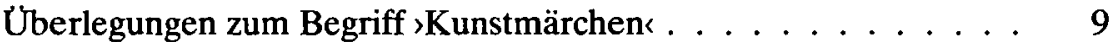

Zweites Kapitel

Probleme der Märchendeutung . . . . . . . . . . . . . . . . 37

Drittes Kapitel

Einheimische Volksmärchen und Volkssagen: Ihre Überlieferung und ihre Spuren in Drama und Dichtung . . . . . . . . . 56

\section{Viertes Kapitel}

Rezeption und Verarbeitung ausländischer Märchen im 18. und 19. Jahrhundert . . . . . . . . . . . . . . . 76

Fünftes Kapitel

Moralistische Tendenzen in englischen Kunstmärchen . . . . . . . 112

Sechstes Kapitel

Charles Kingsley: The Water Babies . . . . . . . . . . . . . . . 135

Siebtes Kapitel

George MacDonalds "Faerie Romances for Men and Women" . . 161

Achtes Kapitel

George MacDonalds Märchen für Kinder . . . . . . . . . . . . . 197

Neuntes Kapitel

Lewis Carrolls »Nonsense-Märchen« . . . . . . . . . . . . . . . . 223

Zehntes Kapitel

Märchen in ironischer Verfremdung . . . . . . . . . . . . 248

Elftes Kapitel

"Minor Masterpieces" und die vergessene Mehrheit . . . . . . 270 
Zwölftes Kapitel

Märchen des spätviktorianischen Ästhetizismus . . . . . . . . . . 291

SchluB . . . . . . . . . . . . . . . . . . . . 324

Anhang ........................... 341

Literaturverzeichnis . . . . . . . . . . . . . . . . 344

Register .................... 356 